\title{
THE NECESSITY OF CONSTRUCTIVE EURASIANISM
}

\section{Mehmet Oğuzhan TULUN-Teoman Ertuğrul TULUN}

\section{Analyst/Analyst}

The notions of Eurasianism prevalent in Turkey are frequently categorized as being inherently at variance with or antagonistic towards the West. Yet, these approaches do not do justice to the term Eurasia itself. Geographically, Eurasia covers a huge landmass from Lisbon to Vladivostok. Thus, Eurasianism for Turkey does not necessarily have to be defined or developed along such lines. In fact, what would be in Turkeys best interest would be to adopt a Constructive Eurasianism that on the one hand values Turkeys institutionalized connections with the West, and on the other hand looks into the potential offered by increased ties with Turkeys east. In this context, this Eurasianism promoted by the Center for Eurasian Studies (AVIM) rests on the rejection of the negative interpretation of Eurasianism, which is interpreted basically as the rejection of the West.

When the Republic of Turkey was founded in 1923, its policy makers had a precise idea about where Turkeys future and interests lay in the international system: the contemporary level of civilization, then embodied by the West. Examining the collapse of the Ottoman Empire, Turkish policy makers concluded that the Empires inability to transform its society, economy, and bureaucracy to meet the needs of a modern state and its inability to keep up with technological progress significantly contributed to its downfall. Western countries (countries in North America and Western Europe), at the time of the founding of the Republic, represented the pinnacle of the modern and successful state and society. With such an example before them, it was evident for Turkish policy makers that the path towards progress for the young Republic was to closely study the Western model of state and society and apply this model in way that would suit Turkeys needs. Yet it was also evident that Turkish policy makers wanted to achieve these goals without severing Turkeys ties from the East.

As is common knowledge, the sweeping reforms carried out in the initial decades of the Republic were based on such a Western model, and Turkey sought to integrate itself with international institutions founded or spearheaded by Western countries. This trend became even more pronounced with the start of the Cold War, when Turkey became the eastern-most outpost of the Western bloc (grouped around NATO) flanking the Eastern bloc (grouped around the Warsaw Pact). In line with its founding principles, Turkey was comfortable in this position and firmly considered itself associated firstly with the Western world. In Western countries too, Turkeys position in the then current configuration of the 
international system was taken as a given.

The end of the Cold War (and thus the end of the threat of the Eastern bloc) automatically lessened the persuasiveness of the above-mentioned assumptions, because the ideologically defined bi-polar world of the Cold War had ended. Up until that time, the political and economic weight of the world was centered around Europe with United States on its left and Russia on its right.

To cut a long story short, the international conjecture, as well as the balance of power, began to change, noticeably so after the beginning of the 2000s. Countries in Central Asia, East Asia, and South-East Asia, which were relegated to secondary importance in terms of Turkeys foreign policy during the Cold War, have risen significantly in importance in various aspects (politically, economically etc.). While Japan and South Korea were already considered economic power houses in the past, based on present day realities, we are now required to list China and India as economic power houses as well, and seriously consider for example the potential offered by Indonesia or the Central Asian republics.

What we see then is the rise of a new power center in Asia, with the weight of the political and economic weight of the world (partially or completely, depending on ones interpretation) shifting from the West to the East. And Turkey is naturally, institutionally, and culturally situated right in the middle of this shift in the international system. Turkey has long-standing and entrenched political and economic ties with Western countries in terms of its NATO and Council of Europe memberships, its European Union candidacy, and its very large trade volume with European countries. Moreover, Turkey has cultural ties with the Central Asian Republics, meaning that Turkey has an inherent advantage in developing its relations with these countries that are situated right in the heart of Asia. Geographically positioned right in the middle of Europe and Asia, Turkey, along with the Central Asian republics, has the natural capacity to serve as a nexus for trade and transportation between these two regions.

The questions that arise from all of this are the following: Especially in a post-Brexit world and after German Chancellor Angela Merkels recent Munich speech, why should Turkey associate itself primarily with the West when Western countries themselves are reexamining their place in the world? Why should Turkey continue to abide by an antiquated term such as the Western bloc and adhere to being this blocs eastern-most outpost when it can do more? Would it not be in Turkeys interest to explore new opportunities for deeper interactions with countries to its East?

This is where the concept of Eurasia comes into play, which is a giant landmass stretching from the Atlantic to the Pacific with Turkey in the middle. For AViM, Eurasianism should be understood in this context. For AVIM, Eurasianism is about understanding Turkeys present and future place in Eurasia, where the present and future power center of the world is and will be situated. Yes, the prevalent notions of Eurasianism share a distrust towards and disillusionment with the West and that Turkey should begin to distance itself from it. However, Eurasianism does not necessarily have to be defined or developed along such lines. 
When one takes into account Turkeys current foreign and trade relations and position in the world, a Eurasianism defined inherently along the lines of anti-Westernism is not going to bring much benefit to Turkey. Turkeys best interest lays in adopting Constructive Eurasianism that on the one hand values Turkeys institutionalized connections with the West, and on the other hand looks into the potential offered by increased ties with Turkeys east.

Turkeys institutionalized connections with the West should under no circumstances be mitigated. Despite the end of the Cold War, NATO maintains its relevance and its position as the most powerful military alliance in the world, and Turkey is one of its key members. Council of Europe membership gives a shared perspective to Turkey with other European countries on notions of state and society, and Turkeys European Union candidacy gives Turkey a powerful incentive to carry out reforms. The fact that neither Turkey nor the EU is willing to cast aside Turkeys candidacy despite all their (sometimes very heated) disagreements over the years is a testament to the value both sides attach to this candidacy. Turkeys trade volume with Europe speaks for itself; European countries are amongts Turkeys biggest trade partners. So, throwing all this away simply because of ones suspicions or distrust towards the West or the Wests relative decline with respect to the East would not be realistic move, nor would it serve Turkeys interest. It should be kept in mind that Asia, to speak in general terms, is a developing region in flux and Turkeys relations with this region are nowhere near as deep as the one it has with the West. In this context, espousing a Eurasianism for Turkey that rejects the West and embraces the East will not serve Turkeys interest.

Having said all of this, the Constructive Eurasianism advocated by AViM requires a proper framework program to be established right from the beginning in order for Turkey to expand its relations in the Asian part of Eurasia. This proper framework, starting from simple bilateral agreements, will allow Turkeys Constructive Eurasianism for example to exist side by side with Russias Neo-Eurasianism in the same geography. Turkeys Constructive Eurasianism should be understood as geared towards encouraging regional cooperation. As such, a framework program will help to differentiate Turkeys Constructive Eurasianism from the likes to Russias Neo-Eurasianism that seeks to establish a sphere of (Russian) influence rather than regional cooperation.

In sum, Constructive Eurasianism, unlike other forms of Eurasianism prevalent in Turkey, will benefit Turkey because it rejects creating new rivalries and antagonisms, and instead seeks to create new avenues for cooperation so that Turkey can position itself properly in a changing world. This will allow Turkey to maintain its integration with the West while at the same time start a new integration process with the East. As such, Constructive Eurasianism will allow Turkey to function as a true nexus between the West and the East.

*Image: GettyImages.com

About the Author: 
Mehmet Oğuzhan Tulun is an AViM Analyst and a doctoral student at Political Science in Ankara University. His research focuses on Eastern Europe, the Caucasus, Asia, Turkish-Armenian and TurkeyArmenia relations, international crimes and history, and the interplay between religion and politics.

Teoman Ertuğrul Tulun is an analyst at Ankara-based think-tank Center for Eurasian Studies. He is a PhD Candidate at Bilkent University Department of Political Science and Public Administration. His area of research include European Union Studies, Social Movements, Xenophobia and Hate Speech-

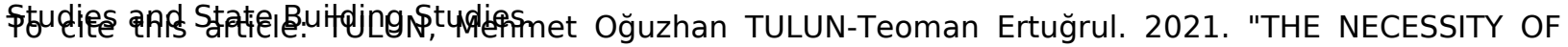
CONSTRUCTIVE EURASIANISM." Center For Eurasian Studies (AVIM), Commentary No.2017 / 51 . June 12. Accessed October 03, 2021. https://avim.org.tr/en/Yorum/THE-NECESSITY-OF-CONSTRUCTIVEEURASIANISM

\section{(2) AVIM}

Süleyman Nazif Sok. No: 12/B Daire 3-4 06550 Çankaya-ANKARA / TÜRKIYE

Tel: +90 (312) 43850 23-24 • Fax: +90 (312) 4385026

@avimorgtr

If https://www.facebook.com/avrasyaincelemelerimerkezi

E-Mail: info@avim.org.tr

http://avim.org.tr

(c) 2009-2021 Center for Eurasian Studies (AVIM) All Rights Reserved 